\title{
The politics of national history in post-colonial Hong Kong
}

Flora L.F. KAN, Faculty of Education, the University of Hong Kong

Flora L.F. Kan is an associate professor in the Faculty of Education, the University of Hong Kong. She teaches and publishes in history education, curriculum studies and education policy analysis.

Tel. +852-2859-2534; fax: +852-2858-5649; Email address: flfkan@hku.hk

Address: Faculty of Education, The University of Hong Kong, Pokfulam, Hong Kong 


\title{
The politics of national history in post-colonial Hong Kong
}

\begin{abstract}
This paper examines how interest groups in Hong Kong have politicised National History, an unpopular school subject, for their own political ends and allied themselves with the PRC against the SAR government and its policy of not making it a single, independent compulsory core subject in the school curriculum. The paper argues that this has been made possible by the 'One country, two systems' administrative structure.
\end{abstract}

Key words: national history, national education, nation building, interest groups 


\section{The politics of national history in post-colonial Hong Kong}

\section{Introduction: the place of national history in the school curriculum}

History education worldwide has been the focus of continual public concern. Osborne points out: 'History and history teaching have become newsworthy in many parts of the world. Whether it is the construction of a national history curriculum in England and Wales; the design of national history standards in the USA; the content of history textbooks in Japan, Israel, and other countries; the development of new curricula in the successor states of the former USSR; or the apparently widespread historical ignorance of students around the world, history and history teaching are in the news' $(2003,585)$. Since national history concerns the interpretation of a country's past, it possesses rich political and cultural capital that helps to legitimise the administration of the current ruling authority. In teaching national history, states invariably aim at fostering students’ national sentiment and hence, at contributing to nation building. In view of the capital value of national history, the public in general and interest groups such as Chinese history subject community, politicians, and journalists in particular present themselves as stakeholders and take part in the national history education debate. In Hong Kong, the politicisation of national history has meant not only that national history has shifted from being the subject of academic debate to one of public discourse, but also that the 
government's provision of national history in the school curriculum has aroused concern amongst the public and is considered a subject of policy debate.

In most countries, history exists either as a single independent subject, as for example, in the People's Republic of China (PRC), Britain and Australia, or as a component of Social Studies as in the United States. In these countries, disputes over history education include its position in the school curriculum and in particular about what to include in the content of History, such as the weighting of national history vis-à-vis the history of other countries, what to emphasise in national history, or the interpretation of national history. Coulby, for example, points out that: '...the overwhelming concentration in history teaching in mostly European states is on national events ... The history of Scotland remains concealed from pupils in the schools of England and Wales, and indeed from those in Scotland itself ...' (2000, 93). In Canada, since the early 1990s, the debate over the teaching of Canadian history has included the following criticisms: 'schools do not teach enough Canadian history and students, therefore, do not know it; the history that is taught is no longer sufficiently national; social history has destroyed the old nation-building narrative and dwells on the negative rather than the positive aspects of Canada's past' (Osborne 2003, 585). The 'history wars' in Australia are characterised by national guilt versus national pride and involve two opposing camps comprising on the one hand, left wing proponents of the 
'black-armband' view of history (Blainey 1993), who depict the Australian past as a deplorable tale of dispossession, and on the other, the conservative and neoconservative exponents of the 'Three Cheers' view of history, who exalt British origins and the achievements of white ancestors (Munro 2007). In Taiwan, the inclusion of Taiwanese history in the history curriculum has all along been a heated debate because the disputed status of Taiwan - as a region or as an independent state - is reflected in the curriculum. According to Vickers and Jones (2005), ‘...for four decades or more, Taiwanese schoolchildren studied a curriculum focused entirely on the history of the central Chinese state and entirely divorced from the Taiwanese context. However, in the progress of democratisation since the 1980s, syllabi and textbooks on the island have changed to reflect the popular sense of Taiwan's distinctiveness vis-à-vis the mainland' (24). In all these countries, however, although there has been contestation over the nature of national history, there has been no contention over its status in the curriculum.

In Hong Kong, however, the major point of contention is not so much what should be included in the content of National History (referred to as Chinese History thereafter) [note1], but more a question of what form the subject should take in the curriculum: whether it should be a single independent subject; a compulsory core subject; or a component of an integrated curriculum. In light of this, it is the intention of 
this paper to inquire into the status of National History since it first appeared in Hong Kong's school curriculum, and how, in the post-colonial period, different interest groups, namely, the Chinese History subject community, politicians and journalists, have stood up against the Special Administrative Region (SAR) government in order to consolidate the status of National History in the school curriculum. In addition, the paper examines how the SAR government, in maintaining its stance on the place of national history in the curriculum, is caught in a dilemma.

\section{The origin and development of national history in Hong Kong: from a half-subject to the struggle to become a compulsory subject}

In the reconstruction of education after World War II, history education existed in the form of a subject called World History in both Chinese Middle Schools (using Chinese as the medium of instruction) and Anglo-Chinese Schools (using English as the medium of instruction). National History, often referred to as Chinese History, first appeared in the 1948 Education Department's Annual Report, which stated that 'in the Anglo-Chinese schools, the Hong Kong Certificate of Education Examination (HKCEE) was revised to include Chinese History and Chinese Culture [as one subject] to give candidates a wider choice' (41). Chinese History and Chinese Culture hence became a subject for S4 and S5 students in Anglo-Chinese schools leading to the HKCEE. In Chinese Middle Schools, however, there was still only World History, 
which was inclusive of the history of China, Europe, America and South East Asia. In Anglo-Chinese schools, Chinese History was separate from Chinese Culture until 1960, when it became a single independent subject for S1 to S3 students. In 1965, Chinese History first appeared as a HKCEE subject for Anglo-Chinese schools. For Chinese Middle Schools, Chinese History also subsequently became a single independent subject in 1962 and 1967 for S1 to S3 and S4 and S5 respectively. From then on, the school curriculum contained two history subjects, namely, World History and Chinese History (Kan et al. 2007, Vickers et al. 2003).

According to Kan (2007), from when Chinese History became a single independent subject in 1967 to the handover of sovereignty in 1997, no major changes were made to the curriculum. Since the Handover, however, two factors have given rise to contestation over the status of Chinese History in Hong Kong: first, the curriculum integration initiative introduced in 2000 by the SAR government as part of its curriculum reform, which aimed at developing students with cross-curricula knowledge and skills; and second, changes to the academic structure of secondary and tertiary education in Hong Kong. During this period, Chinese History teachers, as the major stakeholders of Chinese History, have organised themselves into two teacher associations: the Hong Kong Teachers’ Association of Chinese History Education and the Chinese History Educators Society. These two organisations have become a strong 
subject community (Kan et al., 2007), which from 2000 to the time of writing, has been striving not only to keep Chinese History as a single, independent subject, but also to make it a compulsory core subject.

\section{Chinese History: struggling to maintain its single independent status}

The curriculum reform affected Chinese History when, in 2000, the Education and Manpower Bureau (EMB, later renamed the Education Bureau, EDB) proposed four options from which schools could choose concerning the offering of Chinese History: first, Chinese History as a single independent subject; second, Chinese History and World History merged to form a new subject called New History; third, Chinese History as a school based curriculum to suit the needs of students; and fourth, Chinese History integrated into the subject Integrated Humanities. Although one of the proposed choices was for Chinese History to continue to be a single independent subject, the other choices open to schools meant that Chinese History's status as a single independent subject would be weakened. The proposal ignited public concern over the status of Chinese History, and the Chinese History subject community particularly had to guard against the possible integration of Chinese History and World History, and /or Chinese History and Integrated humanities. Since 2000, views have continuously been expressed in the media against the government's weakening of Chinese History. These views mainly originated from the Chinese History subject 
community, journalists and politicians, with occasional input from ordinary citizens. For example: 'Under colonial rule, students developed a weak sentiment of China, they had little knowledge about Chinese history and culture. Now we should strengthen Chinese History instead of weakening the subject' (Federation of Teachers [a leftist teacher association] Ta Kung Pao 28 November 2000); 'National history is a unique thing to a country. Chinese History can be expanded to cover World History, but not the other way round. It is essential to teach the subject in an ethno-centric manner' (S.T. Kwok, Professor, Chinese University of Hong Kong, Sing Tao Daily 23 April 2000); 'Any proposals to reduce Chinese History education or let schools have the options to choose whether or not to include Chinese History in the curriculum is politically incorrect' (Ma Lik, Legislative councilor, The Sun 15 June 2000); 'Chinese History should be strengthened not weakened' (editorial, Ming Pao 5 April 2000); 'There is nothing wrong with the curriculum. We just need to change the methods and examination. I'll collect people's signatures, and these will be forwarded to the Chief Executive' (L.L. Fung, District Council Member, The Sun 26 April 2000). There have also been special forums in newspapers presenting views against the autonomy given to schools concerning the status of Chinese History. For example, on 27 November 2000, a whole page in the Kung Ching newspaper was devoted to presenting views on this: 'the options for school is a conspiracy, the government wants to 'kill' Chinese History' 
(Leung Bing Wah, chairman, Chinese History education society); 'the next generation is ignorant of national history' (Leung Hon Wah, spokesman, China youth service); and 'an integrated curriculum means destroying Chinese History' (Ip Kin Yuen, lecturer, Hong Kong Institute of Education). In response, the government could only stress that 'After the handover, we all have a sentiment towards Chinese History ... Chinese History should aim at promoting students' sense of belonging to and identification with the nation and its people ... Chinese History will not be cancelled but will be strengthened' (Fanny Law, Director of Education, The Sun 15 April 2000,); 'The merger is to let students view the world from the Chinese perspective and vice versa. We do not intend to weaken Chinese History, but on the contrary, the new curriculum will develop students’ national identity’ (W.N. Bau, Principal Curriculum Development Officer, Curriculum Development Institute, EMB, South China Morning Post 7 April 2000). The government was caught in the dilemma of how to introduce curriculum integration, which was one of the major initiatives in the curriculum reform, and at the same time, keep the independent status of Chinese History. In the midst of the heated debate, the PRC's Minister of Education, Chen Zhili, entered into the dispute, telling the Sunday Morning Post on 28 May 2000 that: 'Chinese History is part of world history, but as Chinese, we should learn Chinese history thoroughly. The subject should be introduced to students in a very comprehensive and scientific way. There needs to be 
more academic discussion on whether it should be merged into world history as a small part'. This remark made by the Beijing officer was regarded as a warning signal for the SAR government: after 1997, Chinese History was a nation-building subject, and anything done to weaken the status of the subject would not be welcomed.

\section{Chinese History: striving to become a compulsory core subject}

The education reform brought about a significant change in the Hong Kong secondary and tertiary academic structure. In 2003, the government proposed that the 3-year junior secondary (S1-S3), 2-year senior secondary (S4-S5, leading to the Hong Kong Certificate of Education Examination), 2-year sixth form (S6-S7, leading to the Advanced-level Examination) and 3-year university academic structure be changed to a 3-year junior secondary (S1-S3), 3-year senior secondary (S4-S6, leading to the Hong Kong Diploma of Secondary Education Examination) and 4-year university academic structure. In the new academic structure, there would be four core compulsory subjects for senior secondary level: Chinese language, English language, Mathematics and the newly included Liberal Studies. In the debate over education reform, the Chinese History subject community, together with a number of like-minded politicians and journalists, made use of this opportunity to propose that Chinese History should be included as a fifth compulsory core subject in the new senior secondary curriculum. In other words, the interest groups had escalated their demands: whereas before, they had 
asked only for Chinese History to be maintained as a single independent subject, now they were insisting that it be made a compulsory core subject. They were well aware of the rich political capital to be made out of Chinese History, a subject that could fulfill the needs of national education and nation building. For example, the following government policy addresses, made soon after the Handover and in 2009 respectively, illustrated the important role of Chinese history in national education:

We will incorporate the teaching of Chinese values in the school curriculum and provide more opportunities for students to learn about Chinese history and culture. This will foster a stronger sense of Chinese identity in our students.... As we face the historic change of being reunited with China, for every individual there is a gradual process of getting to know Chinese history and culture, so as to achieve a sense of belonging (C.H. Tung, Chief Executive, HKSAR, Policy Address 8 October 1997.)

The Government spares no effort in promoting national education, which is a long-term mission. We will strengthen the elements on China in various key learning areas under the primary and secondary curricula. We will also organize Mainland exchange activities for students as part of the national education programme. By aligning experiential learning with curriculum objectives and content, we hope to deepen national education. (Donald Tsang Yam Kuen, Chief Executive, HKSAR, Policy Address 14 October 2009)

Another key figure in Hong Kong who made use of the political capital of Chinese history was Chow Chuen Ho, a member of the government's National Education Subcommittee, who stated that it would be desirable to introduce patriotic education in primary and secondary schools. He added that in order to promote patriotism among students, the 'glorious history' of the PRC could be incorporated into the national 
anthem footage, which is played daily on television before the evening news (Ming Pao 25 October 2004). In the face of heated recommendations for making use of Chinese history to enhance national education, the government had to appease the different interest groups, in particular, the Chinese History subject community. Therefore, on the official webpage, the chief curriculum development officer, Cheung Wing Hung, stated that "Chinese History is one of the key avenues to promote national education. In addition, not only Chinese History teachers, but all teachers are held responsible for implementing national education” (EDB a).

Chinese History's political capital was significantly enhanced when, on the tenth anniversary of Hong Kong’s return to China, the president of the PRC, Hu Jintao, said: 'youngsters are the future hopes of Hong Kong and China. We have to pay attention to educating them with national education ...' (Hu Jintao 2007). Hu’s statement was taken as a golden opportunity for the Chinese History subject community and politicians to gain political capital. They all maintained that since Chinese History could contribute to national education, it should be made a compulsory core subject. For example, the principal of Elegantia College, Tso Kai Lok, in echoing the statement made by president $\mathrm{Hu}$, argued that during colonial rule, modern and contemporary Chinese history was deliberately avoided [note 2]. As a result, students knew very little about the modern history of China. Therefore, to enhance national education, he urged the 
government to put more emphasis on Chinese history education and not to merge Chinese History with Integrated Humanities (Wenwei Pao 12 July 2007). In another example, Ming Pao, regarded as one of the most creditable newspapers, emphasised in its editorial on 14 July 2007 that Chinese History should be made a compulsory subject. Similarly, the president of the largest teacher union, the Professional Teachers Union (PTU), Cheung Man Kwong, who is also a legislative councilor and considered a dissident with regards to the PRC, held the view that 'as Chinese History is an important component of national education, it should be strengthened as a compulsory core subject' (Cheung Man Kwong 2007). For its part, the SAR government, in response to president Hu's remark, focused on highlighting the ways in which Chinese History could contribute to national education and avoided the issue of its status in the school curriculum. For example, the Secretary for Home Affairs, Tsang Tak Sing, recommended that in enhancing national education, Chinese history should focus on the recent 30-year period of reform and opening up of China. In addition, Tsang regarded it as desirable to make use of national achievements such as space technology, the Beijing Olympic Games, and the construction of the Three Changjiang River Gorges in order to promote students' national identity and ethnic pride (Home Affairs Bureau, From the Secretary). Clearly, the Secretary of Home Affairs wanted to use Chinese history as propaganda for PRC governance, and his proposal reveals how the 
emergence of China as a world power has helped to define the scope of national history for Hong Kong. The Chinese History subject community understands very well the difficult position confronting the SAR government with respect to the status of Chinese History, and they therefore seize any opportunities that arise to put pressure on the government. On 26 June 2008, three education organisations, namely, the Chinese History Educator Society, the Federation of Teachers and Education Convergence, jointly published a statement demanding that the Chief Executive, Donald Tsang, make Chinese History an independent core subject in the secondary school curriculum. The statement even went so far as to say that if the government made no response to their request, they would petition the Chinese Prime Minister, Wen Jiabao and China's National Education Bureau in protest against the SAR government's diminishing the status of national education. In addition, they organized a pressure group entitled 'Joint action group for the promotion of national history education' (Sing Tao Daily 27 June 2008), which not only sent questionnaires to secondary schools inquiring about their offering of Chinese History, but also held press conferences expressing their discontent over the status of Chinese History. On 6 October, 2009, representatives of the three teacher organisations went to the Legislative Council and complained that the number of schools offering Chinese History was decreasing. In the meeting, the legislative councilor, Regina Ip, reiterated that Chinese History was an important part of national 
education and should be made a compulsory core subject. She also promised to pursue this further with the government (Sing Tao Daily 7 October 2009).

Views expressed by the Chinese History subject community and politicians exerted political pressure on the government and placed it in an embarrassing situation. On the one hand, if the government agreed to the demands of the interest groups, it would upset the planning of curriculum reform and at the same time threaten the ruling authority of the government. On the other hand, the government could not simply ignore the requests of the interest groups, particularly in view of the PRC's support for these requests, as Chinese History had been considered a vehicle for nation-building since decolonisation. Therefore, in response to the demands, the government had to explain to the public that it did recognise the importance of the subject and that efforts were being made to ensure that schools offered enough Chinese history lessons. K.K. Chan, Principle Assistant Secretary of the Education Bureau, made it known to the public that: "the official curriculum has clearly specified the inclusion of Chinese history in each key learning stage so as to ensure that students are provided with the opportunity to come to know national history and culture' (EDB b). This remark shows that in the contestation with interest groups, the government has been highly cautious and has had to make it clear that it has made every attempt to promote Chinese history education, and that the public should not have a wrong conception 
that the subject is being de-emphasised. In addition, the Chief Curriculum Development Officer, Lee Chi Hung, informed the public that concerning the offering of Chinese History in schools:

...in the junior level (S1-S3) most schools offer it as a single independent subject. Recently we have made a survey and found that $60 \%$ of humanities teachers consider junior level students have a better understanding of national history and culture. In regard to national identification, 50\% students identify themselves as Chinese (EDB c).

On 28 May 2008, the EDB on its official webpage uploaded a special message reiterating the importance of Chinese History:

85\% of secondary schools offer Chinese History as a single independent subject in junior level [S1-S3]. Some schools have adopted different modes in offering Chinese history, for example, as an element in the subject Integrated Humanities, History and Culture etc. The purpose is to allow students to learn Chinese history from multiple perspectives. The EDB has been monitoring schools closely to see if they have duly followed the instructions regarding including the teaching of Chinese history in the curriculum.' (EDB d)

This shows that in defending its position, the government had changed its tactic from responding passively to taking part actively in disseminating information of the study of the history of China. On the other hand, as far as the status of Chinese History was concerned, the government tried to avoid any further disputes over it.

The government had never before felt the need to explain publicly the conditions under which schools could offer a particular subject. The political sensitivity surrounding Chinese History forced the government to be mindful of the criticisms from interest groups and the general public. In response to Legislative Council 
members' suggestion that Chinese History be made a compulsory core subject, the government had to shift the focus and argue instead that:

The curriculum of Liberal Studies comprised core modules on "Hong Kong Today" and "Modern China" which covered, among others, areas on the historical and cultural developments of Hong Kong and China. ...Like many overseas countries which had developed public examination systems, national history or world history was offered as an elective subject for students in Hong Kong. ...According to the annual surveys on teachers and students, their sense of national identity had been increasing in the past years. (Legislative Council, 6 July 2009)

The SAR government was aware of the role of Chinese history in promoting national education, but the unpopularity of Chinese History with students and the practical problems of teacher deployment in schools were also keen concerns of the government. These might be some of the reasons why the government continued to maintain that schools could choose the most appropriate format to offer Chinese history, rather than making it a compulsory core subject.

\section{Chinese History: an unpopular 'nation building' subject}

Throughout this dispute over the status of Chinese History in the school curriculum, little concern has been expressed by the Chinese History subject community and politicians over the criticisms that have been made against Chinese History, and how it can be made a more effective and interesting and popular subject. According to Kan (2007), since the 1960s, Hong Kong's Chinese History has always been criticised for being content-heavy and because students found it boring and irrelevant. For example, 
in explaining the reasons for the unpopularity of Chinese History, Feyl (1966) noted that: 'The textbooks in Chinese History are too factual. Chinese History should be written from a wider knowledge of China in its world setting. The perspective of available textbooks is not clearly applicable to the contemporary Hong Kong situation' (24). In the 1970s, comments were made about teachers' use of Chinese History textbooks: ‘... rarely did teachers challenge views presented in the textbook. Teachers tended to use only one textbook to teach and assume that it could solve all the problems in Chinese history learning (Wu 1973, 172). In Kan’s study (2007), criticism was made against the traditional teaching method and examination '... Chinese History teaching remained almost exclusively concerned with the transmission of established knowledge. Students were simply expected to reproduce 'model answers' in the examinations, and so it is not at all surprising that Chinese History was an unpopular subject with them' (76-77).

An indicator of the unpopularity of Chinese History is revealed in the number of S4 students choosing to do Chinese History in their three-year senior secondary course (S4-S6) leading to the Hong Kong Diploma of Secondary Education. Statistics from the Education Bureau on 6 January, 2010 showed that 12,867 students had opted for Chinese History, which was only $16.4 \%$ of all S4 students, lower than Geography (22.5\%) and Economics (34.4\%), and only half the number of students who had sat 
for the Chinese History Certificate of Education Examination (S5) in 2009. Thus, while the Chinese History subject community and politicians present themselves as patriots, agents of decolonisation and guardians of Chinese History education, Chinese History remains as it always has been: content-heavy, boring and unpopular. In view of this, schools would welcome the autonomy to decide on the status of Chinese History.

\section{Conclusion: Chinese History - a subject for 'political and public consumption'}

Since the Handover in 1997, issues relating to Chinese History as a school subject have become a public concern. Interest groups comprising the Chinese History subject community, politicians and journalists, in expressing their views about Chinese History, have created a climate of opinion which has placed the government in a dilemma. The ways in which these interest groups have taken the lead and formed public opinion in regard to the status of Chinese History is unprecedented in Hong Kong’s curriculum history. This corresponds to Goodson's (1988) remark about school subjects in which he argues that school subjects represent substantial interest groups. Chinese History interest groups with respect to the issues discussed in this paper further extend the Chinese History interest group depicted by Kan et al (2007). In Kan's study, the interest group refers to the subject community, which comprised teachers, academics, textbook writers and officials, who controlled the emergence and 
development of Chinese History, especially during colonialism. In this study, however, the interest groups are not confined to the Chinese History subject community, but include politicians and journalists. These interest groups have striven to make Chinese History not only a single independent subject, but also a compulsory core subject in the new senior secondary curriculum. It could be said that anyone can assume a stakeholder's role as it has become politically correct to be highly concerned about issues relating to national history and particularly its status in the school curriculum. Since decolonization, Chinese History has become a subject for 'political and public consumption’ (Phillip 1998, 41).

It should be emphasised, however, that the main point of contention regarding Chinese History has been its status in the school curriculum. Curriculum conceptions and issues of teaching and learning have seldom been the foci of the disputes. For the SAR government's part, it has never really been concerned about the nature of Chinese History. It has always been content to go along with the wishes of the curriculum developers as long as there is nothing controversial in the curriculum that is, controversial topics which might portray the PRC in a negative light. The SAR government is well aware, however, of the unpopularity of Chinese History, and that if it enforced Chinese History as a compulsory core subject, there would be a fierce backlash from schools because of its unpopularity with students and because of the 
already over-crowded timetable and problems of teacher deployment. This explains its maintaining its policy of offering choices to secondary schools, even in the face of opposition on the part of the interest groups and their alliance with the PRC.

As for the Chinese History subject community, some individuals have political aspirations and are keen to secure their positions in the political arena, such as the legislative council. They feel that their political interests can be furthered by publicly allying themselves with the PRC. In terms of the actual Chinese History curriculum, no substantial recommendations have been made by these interest groups; they have mainly been concerned with the form of the subject, that is, its status, and have placed little or no emphasis on its substance, that is, curriculum knowledge. As Eggleston points out: 'curriculum knowledge is accepted as a received body of understanding that is given, even ascribed as predominantly non-negotiable, non-dialectic and consensual' (Eggleston 1977, 52). Within the interest groups, this perception is especially prevalent among politicians and journalists, as they are not directly involved in teaching the subject. For the Chinese History subject community, some consider that the existence of Chinese History as a single, compulsory core subject is the most effective way to reflect decolonization. Since Chinese History already existed as a single independent subject, the issue of the amount of national history vis-à-vis the history of other countries is thus not on the contestation agenda. Hence, 
'the chronological approach adopted by curriculum developers, who have insisted that Chinese History needs to be studied in its entirety before one can come to appreciate the essence of Chinese culture ... has resulted in the whole 3,000 years of history being repeated three times (S1-S3, S4-S5, S6-S7) in secondary schools in ever-increasing detail' (Kan 2007, 141).

In the disputes, although there has been no evidence to support claims that the PRC government has directly interfered in securing the status of Chinese History, the indirect influence of the PRC should not be under-emphasised. The 'One country, two systems' administrative structure after the Handover has made the politics of history education different from and more complicated than those of other countries in that it has made it possible for various interest groups to ally themselves with the PRC and to manipulate Chinese History for their political ends. In Hong Kong, Chinese History interest groups, who appear at the forefront, are teachers, politicians, and journalists. However, behind the scenes, the PRC government is tacitly playing an influential role. The views put forward by the PRC's Minister of Education concerning the place of Chinese History in the school curriculum, and speeches made by the PRC leaders on national education in Hong Kong can be viewed as evidence of the PRC government's support for Chinese History being given a prominent status in the school curriculum. Interest groups have thus gained the support of the PRC government in striving for the 
compulsory core status of Chinese History. The threats made by the Chinese History subject community and politicians that they were going to report to the PRC government about the SAR government's weakening of Chinese History as a result of its policy shows how a school subject may be manipulated. Hong Kong's case can be added to the literature on the history of school subjects, in particular, in decolonised countries as it is precisely the 'One country, two systems' administrative structure that has made possible the contestation between the various interest groups and the PRC on one side and the SAR government on the other. In addition, the ways in which interest groups in Hong Kong struggle for the status of Chinese History echo Goodson's social construction of school subjects. According to Goodson (1994), school subjects are socially and politically constructed and the actors include politicians, teachers, academics and school inspectors, who, in the course of a subject's development, struggle for status, resources and territory (111-119). The difference in the case of Hong Kong, however, is that school inspectors are government officials and are not allied with journalists, politicians and the Chinese History subject community in fighting for the status of Chinese History. Since the Handover, the independent status of Chinese History has been secured, but whether or not Chinese History can become a compulsory core subject has yet to be shown. Nevertheless, it is certain that with the support of the PRC government behind the 
scenes, interest groups will continue their struggle with the SAR government over the status of Chinese History in the school curriculum. 


\section{Acknowledgements}

I acknowledge the useful comments made on the earlier draft of this paper by a reviewer.

\section{Note}

1. Chinese History is a school subject, taught in Chinese; it differs from History, which refers to the discipline of history or history in general.

2. The chronological scope has been extended to 1976 for S1-S3 and S4-S5, in 1975 and 1990 respectively. 


\section{References}

Altbach, P.G. and Kelly, G.P. (Eds) (1978) Education and Colonialism. New York: Longman.

Blainey, G. (1993) Drawing up a balance sheet of our history, Quadrant_37 (7-8), July/August.

Cheung Man Kwong (2007) Policy Address on education. Available online at: www.cheungmankwong.org.hk/debate/detate20071024.htm (accessed 28 October 2010). (in Chinese)

Coulby, D. (2000) Beyond the National Curriculum: Curricular Centralism and Cultural Diversity in Europe and the USA. London: RoutledgeFalmer.

Education Department (1948) Annual Report. Hong Kong: Government Printer.

Education Bureau (EDB a) National education: rationale. Available online at: http://resources.edb.gov.hk/mce1/nebook/pdf/rationale.pdf (accessed 26 October 2010). (in Chinese)

Education Bureau (EDB b) National education. Available online at: http://resources.edb.gov.hk/mce1/nebook/pdf/rationale.pdf (accessed 27 October 2010). (in Chinese)

Education Bureau (EDB c) Chinese History keeps up with the times. Available online at: http://www.edb.gov.hk/index.aspx?nodeID=2204\&langno=2 (accessed 27 October 2010). (in Chinese)

Education Bureau (EDB d) Positive view of Chinese History. Available online at: http://www.edb.gov.hk/index.aspx?nodeID=6611\&langno=2 (accessed 28 October 2009). (in Chinese)

Fehl, N.E. (1966) History in Hong Kong Middle and Secondary Schools: A Research Project of the Chinese University of Hong Kong. Hong Kong: Chinese University Press.

Goodson, I. (1988) The Making of Curriculum. London: Falmer Press.

Goodson, I. (1994) Studying Curriculum. Buckingham: Open University Press. 
Home Affairs Bureau. From the Secretary. Available online at: http://www.hab.gov.hk/tc/about_us/from_the_desk_of_secretary_for_home_affair s/shaArticles.htm (accessed 26 October 2010). (in Chinese)

Hong Kong Special Administrative Region (HKSAR) (1997) Policy Address. Hong Kong: Hong Kong Government.

Hong Kong Special Administrative Region (HKSAR) (2009) Policy Address. Hong Kong: Hong Kong Government.

Hu Jin-tao (2007) Speech made at the tenth anniversary of Hong Kong's return to China. Available online at: http://big5.cri.cn/gate/big5/gb.cri.cn/14714/2007/06/30/107@1657031.htm (accessed 30 October 2009). (in Chinese)

Kan, F. L. F. (2007) Hong Kong's Chinese History Curriculum from 1945: Politics and Identity. Hong Kong: Hong Kong University Press.

Kan, F., Vickers, E. \& Morris, P. (2007) Keepers of the sacred flame - patriotism, politics and the Chinese history subject community in Hong Kong, Cambridge Journal of Education, 37 (2), 229-247.

Legislative Council (2009) Liberal Studies. Panel on Education, CB(2)2122/08-09(02), 6 July 2009.

Munro, D. (2007) The history wars, Journal of Social History, 40 (3), 786-788.

Osborne, K. (2003) Teaching history in schools: a Canadian debate, Journal of Curriculum Studies, 35 (5), 585-626.

Phillip, R. (1998) Contesting the past, constructing the future: History, identity and politics in schools, British Journal of Educational Studies, 46 (1), 40-53.

Vickers, E. \& Jones, A. (2005) History Education and National Identity in East Asia. New York and London: Routledge.

Vickers, E., Kan, F. and Morris, P. (2003) Colonialism and the politics of 'Chinese History' in Hong Kong's schools, Oxford Review of Education, 29 (1), 95-111. 
WU, Y.F. (1973) Problems of Chinese history teaching and learning, Stadium, 4, 172. (in Chinese) 